\title{
A NEW GENUS OF THE SUB-FAMILY LAMPRIMIDES OF LACORDAIRE.
}

\author{
By William Macleay, F.L.S., \&c.
}

In a Paper read before this Society at the April meeting of this year, entitled "Revision of the Genus Lamprima of Latreille," I described under the name of Lamprima Muelleri a very beautiful and distinct female insect of the group, mentioning at the time that I thought it likely that the discovery of the male would probably prove it to be generically distinct from Lamprima. My surmise turned out to be correct. Mr.C. French of the Botanical Museum of Melbourne, from whom I received the specimen originally described, has now sent me for inspection a male specimen of what $I$ feel convinced is the same species. It is I think the most beautiful insect $I$ have ever seen, not surpassed in brilliancy of metallic lustre and size by the most gorgeous of the Buprestidæ. Though closely allied to Lamprima, it cannot be placed with it, if Dr. Gestro's genus Neolamprima be admitted as a genus, for that is undoubtedly much nearer the typical Lamprima, than the present insect. Dr. Gestro gives as the only distinctive character of his genus Neolamprima the long and many-toothed mandibles. One of these characters only applies to the present insect for which I propose the name of Phalacrognathus from its glabrous mandibles.

This genus may be briefly characterised as follows, in the absence of other species, for I have often found the inconvenience of too narrowly defining the boundaries of genera in a country where fresh species are constantly turning up.

"Mandibles very long, porrect, curving upwards, smooth, glabrous, and unarmed on the lower and inner edges. Basal joint of antennæ scarcely clavate, and as long as the other joints combined. Fore tibiæ of the male without the foliate spur. 
Phalacrognathus Muelleri. Macleay.

Lamprima Muelleri. Proc. Linn. Soc., N. S. Wales, Vol. X., p. 135, Female.

Male. Head short, angular before the eyes, emarginate in front, quite smooth, and of a brilliant dark metallic green. The mandibles which are of a black colour, exceed in length the head and thorax conjoined, they have a few minute teeth at the inner base close to the mouth, and a strong horn pointing upwards close to the head, from thence they extend forwards, curving upwards in two long smooth parallel shafts, grooved without and fluted within and terminate in two broad flattened diverging points; there is no vestige of hair or pile.

The thorax is much wider than long, moderately convex and of a dull brassy hue; the anterior portion of the sides have a broad nitid margin, the posterior is crenulated as in the female, the base is narrowly margined and slightly sinuate, the median line is almost obsolete. The elytra differ from those of the female, in being entirely without punctures, in greater brilliancy of metallic splendour, in having the lateral margin crenulated for some distance behind the shoulders, and more distinctly emarginate and narrowed towards the apex. The anterior tibiæ are strongly toothed externally along their whole length and the extension of the anterior femur on each side of the knee-joint is very conspicuous.

Long (mand. incl.) 24 lines.

This description must of course be read with my previous one of thefemale, as it is only the sexual distinctions which Ihavenowgiven.

I have been unable, I regret to say, to examine the trophi so closely as I could have wished, as it is impossible even in the case of insects of such large size, to investigate the parts of the mouth without dissection, and that of course is out of the question with unique specimens; but I believe they vary little from those of Lamprima.

Mr. French has given me no nearer approximation to the habitat of this magnificent insect than "North Australia." 


\section{$2 \mathrm{BHL}$ Biodiversity Heritage Library}

Macleay, W. 1885. "A new genus of the sub-family Lamprimides of Lacordaire." Proceedings of the Linnean Society of New South Wales 10, 473-474. https://doi.org/10.5962/bhl.part.17942.

View This Item Online: https://www.biodiversitylibrary.org/item/30482

DOI: https://doi.org/10.5962/bhl.part.17942

Permalink: https://www.biodiversitylibrary.org/partpdf/17942

\section{Holding Institution}

MBLWHOI Library

\section{Sponsored by}

MBLWHOI Library

\section{Copyright \& Reuse}

Copyright Status: NOT_IN_COPYRIGHT

This document was created from content at the Biodiversity Heritage Library, the world's largest open access digital library for biodiversity literature and archives. Visit BHL at https://www.biodiversitylibrary.org. 